\title{
CATHERINE DENEUVE E LOUIS VUITTON: A PUBLICIDADE DE LUXO ANALISADA SOB O ESPECTRO DA SEMIÓTICA PEIRCEANA
}

\section{APPLIED SEMIOTICS: ANALYSIS OF AN ADVERTISING PIECE OF THE LOUIS VUITTON LUXURY BRAND UNDER THE SPECTRUM OF PEIRCENA THEORY}

\author{
Carolina Boari Caraciola*
}

\begin{abstract}
Resumo
0 presente artigo analisará uma peça da campanha publicitária Journey, da marca de luxo Louis Vuitton, estrelada pela atriz francesa Catherine Deneuve, sob o prisma da semiótica de extração peirceana. A análise da publicidade, sob o espectro da teoria semiótica, permite explicitar o potencial comunicativo do anúncio a que se refere, uma vez que as estratégias semióticas utilizadas por uma marca são fatores essenciais à sua constituição como marca, sendo, portanto, de fundamental importância para a compreensão de sua natureza, perfil e efeitos emocionais e funcionais. Sendo assim, pode-se afirmar que a mensagem publicitária provoca efeitos de sentido no receptor e, com o auxílio da semiótica, é possível compreender como esse campo de sentidos ocorre.
\end{abstract}

Palavras-chave: Publicidade. Semiótica peircena. Luxo. Louis Vuitton.

\section{Abstract}

This article will analyze a piece of the advertising campaign Journey, of the luxury brand Louis Vuitton, starring the french actress Catherine Deneuve, under the prism of peircean extraction semiotics. The analysis of advertising, under the specter of semiotic theory, makes it possible to make explicit the communicative potential of the advertisement to which it refers, since the semiotic strategies used by a brand are essential factors for its constitution as a brand and are therefore of fundamental importance to the understanding of their nature, profile and emotional and functional effects. Thus, it can be affirmed that the advertising message causes effects of sense in the receiver and, with the help of semiotics, it is possible to understand how this field of senses occurs.

Keywords: Advertising. Peircena semiotics. Fashion. Luxury.

\section{Datas de submissão e aprovação do artigo}

Submissão: $27 / 11 / 2018$

Aceito: $21 / 8 / 2020$

\footnotetext{
* Pós-doutoranda em Comunicação pela Escola de Comunicações e Artes (ECA/USP). Doutora em Comunicação e Semiótica pela Pontifícia Universidade Católica (PUC/SP), com a tese: "Evolução, significados e marketing publicitário do luxo. Estudo de caso da marca Louis Vuitton sob o prisma da semiótica". Mestre em Educação, Arte e História da Cultura, pela Universidade Presbiteriana Mackenzie, com a dissertação "A arte na publicidade de uma marca de luxo". Pós Graduação em Comunicação com o Mercado pela ESPM. Graduação em Propaganda e Marketing (ESPM). Graduação em Direito (FMU). Parecerista da Revista Signos do Consumo. Pesquisadora do mercado de luxo. Email: carolboari@yahoo.com.br.
} 


\section{CONSIDERAÇÕES SOBRE O MÉTODO DE ANÁLISE}

A análise da peça publicitária da campanha Journey, da marca de luxo Louis Vuitton, protagonizada pela atriz francesa Catherine Deneuve, partirá da fenomenologia, cuja função é "[...] apresentar as categorias formais e universais dos modos como os fenômenos são apreendidos pela mente" (SANTAELLA, 2012, p. 7). Tais categorias são denominadas como primeiridade, secundidade e terceiridade.

A primeiridade relaciona-se ao acaso, é uma simples possibilidade, um ato contemplativo de imersão na qualidade e no sensível. Na primeiridade, há uma sugestão, ou evocação como possibilidade de funcionar como signo. Nesse momento de contemplação, as referências são abandonadas, procurando, apenas, apreender o modo como o fenômeno se apresenta. O sentimento, na primeiridade, é vago, não havendo a mediação de outros signos. Os signos de primeiridade são denominados quali-signos, ou seja, o poder de sugestão de uma qualidade possibilita o funcionamento do signo.

A secundidade relaciona um fenômeno primeiro a um segundo, estando ligada às ideias de força bruta, ação e reação, conflito, resistência, esforço, aqui e agora. 0 estado contemplativo se esvai e o fenômeno se apresenta como realidade concreta, na sua natureza de sin-signo, um signo de existência, "[...] onde 'sin' quer dizer singular" (SANTAELLA, 2012, p. 13). Secundidade começa quando um fenômeno primeiro é relacionado a um segundo fenômeno qualquer (CP, 1.356-359). É a categoria da ação, do fato, da realidade e da experiência no tempo e no espaço: "Ela nos aparece em fatos tais como o outro, a relação, compulsão, efeito, dependência, independência, negação, ocorrência, realidade, resultado." (NÖTH, 2003, p. 64)

A terceiridade representa o efeito que o signo provocará em um possível interpretante. Os signos de terceiridade são denominados de legi-signos, em função de seu caráter de lei. Na terceiridade, os fenômenos são interpretados a partir de associações advindas de conhecimento prévio, as experiências colaterais. A terceira categoria corresponde à definição de signo genuíno, pois este é capaz de produzir outro signo, o que corresponde ao processo de semiose infinita; sendo assim, a terceiridade é um processo de crescimento contínuo. Terceiridade é a categoria que relaciona um fenômeno segundo a um terceiro (CP. 1.377/ss): “É a categoria da mediação, do hábito, da memória, da continuidade, da síntese, da comunicação, da representação, da semiose e dos signos." (NÖTH, 2003, p. 64)

A análise da peça publicitária terá início a partir do ponto de vista qualitativoicônico, detendo-se aos aspectos qualitativos da publicidade, tais como cores, linhas, texturas, formas, volume, movimento, aspectos presentificados em uma primeira apreensão, ou seja, referem-se "[...] à impressão que brota da primeira olhada". Esse primeiro nível de análise também desperta qualidades abstratas, bem como a previsão de "[...] associações por semelhança que essas qualidades estão aptas a produzir" (SANTAELLA, 2012, p. 70). As relações de associações por semelhança são denominadas icônicas.

Em seguida, o ponto de vista singular-indicativo analisará o anúncio como algo existente em espaço e tempo determinados. As qualidades existentes serão examinadas de acordo com sua "manipulação e uso".

Por último, o ponto de vista convencional-simbólico analisará o "poder representativo do produto", no caso em questão, da publicidade, o que ela 
simboliza, os valores culturais que lhe foram transferidos, a imagem da marca e, de qual maneira a publicidade "[...] está contribuindo ou não para a construção ou solidificação da marca”. (ibid, p. 71)

As análises seguirão esses três pontos de vista mencionados anteriormente como guias de observação. Mas, inevitavelmente, em alguns momentos, os aspectos qualitativos-icônicos, singulares-indicativos e convencionais-simbólicos escorregam uns para os outros, pois secundidade pressupõe primeiridade e terceiridade pressupõe ambas. Isso significa que a análise será tanto mais justa quanto mais puder evidenciar esse processo que se assemelha a uma caixinha chinesa.

A imagem escolhida faz parte de um campo visual delimitado pelos contornos da fotografia, sendo que os elementos "[...] são visíveis até um ângulo limitado para a direita e esquerda e ainda mais limitado para cima e para baixo" (SANTAELLA, 2005, p. 185-186). A fotografia da campanha utiliza o sistema ocidental de leitura, ou seja, da esquerda para a direita, na diagonal de cima para baixo, sendo que o nome da marca está colocado embaixo, na parte direita da imagem. A assinatura da campanha é o nome Louis Vuitton, escrito por extenso, sem o logotipo da grife. 0 nome da marca, bem como a legenda, que se diferenciam de acordo com cada anúncio, representam a parte verbal da publicidade.

O nome da marca, homônimo ao de seu fundador, é carregado de referências que se relacionam à tradição, ao luxo, à sofisticação e distinção, estando posicionado no canto inferior direito dos anúncios, gerando um efeito espelho em relação à celebridade. Dessa relação, pode-se concluir que a marca confere diferenciação a seus usuários, ocorrendo um processo de transferência de significado por similaridade. "O consumidor de repente 'enxerga' a similaridade entre a celebridade e o produto e está preparado para aceitar que os significados da celebridade estão no produto." (MCCRACKEN, 2012, p. 122)

Nesse contexto, o nome da marca funciona como um signo genuíno, ou seja, um símbolo. Ele, “[...] além de sua função verbal [...] possui uma dimensão nãoverbal, icônica, que incorpora, por conotação, significados complementares ao próprio nome." (PEREZ, 2004, p. 53)

O nome da marca, escrito por extenso, lettering, é utilizado em letras maiúsculas, caixa alta, o que confere estabilidade, em função da manutenção de sua forma, sendo uma fonte sem serifas, similar à Futura, com legibilidade apropriada, em função de sua construção geométrica. As qualidades da tipografia que desenham o nome Louis Vuitton geram um efeito de sentido positivo ao serem transferidas à marca, corroborando seus valores de tradição, estabilidade, qualidade, elegância, sobriedade. A cor preta, utilizada no lettering, remete à tradição da marca e sua elegância. "[...] a renúncia às cores permite que o luxo se manifeste por si só [...] o preto é a mais nobre das cores." (HELLER, 2013, p. 150)

Soma-se, a isso, o uso da cor branca, como fundo para o nome da marca, que na esfera emocional gera efeitos tais como sofisticação, moda, luxo, status, glamour. O branco remete à limpeza, sendo considerada a cor da verdade, do estilo minimalista, é imaculada. "O branco como cor proeminente, é usado também por reis e rainhas nas ocasiões mais importantes [...]." (ibid.)

A grafia da marca Louis Vuitton se assemelha, por similaridade, com a inscrição do nome de Luís XIV, o rei Sol, nos textos da época da monarquia, que se referiam ao rei como LOUIS LE GRAND “[...] era assim, em letras maiúsculas, que 
seu nome figurava frequentemente no meio de textos em caixa baixa." (BURKE, 1994, p. 47)

A publicidade é o elo entre o consumidor e a empresa que, valendo-se de estratégias persuasivas, objetiva efetivar a compra de determinado produto ou informar sobre algum assunto específico. Porém, a publicidade não é o único elemento que destaca a marca, pois esta possui um grande número de outras manifestações "[...] que funcionam, então, como tantos outros atos discursivos [...]" (SEMPRINI, 2006, p. 106).

Portanto, a referida campanha será analisada sob a perspectiva da semiótica peirceana, com o escopo de identificar quais são as características, os traços e os atributos específicos apresentados na publicidade da marca de luxo Louis Vuitton, campanha Journey, veiculada no ano de 2008, com a atriz Catherine Deneuve.

[...] as relações entre marketing, publicidade e semiótica estão a cada dia mais evidentes, tendo em conta a complexificação da nossa sociedade que cada vez mais consome símbolos construídos em grande parte pela publicidade do mundo capitalista. (PEREZ, 2004, p. 142)

Os conceitos acima serão aplicados à campanha Journey, da marca de luxo Louis Vuitton, em específico à estrelada pela atriz francesa Catherine Deneuve. Dessa forma, marca Louis Vuitton aqui funciona como signo, aliás um signo complexo, como são complexos quase todos os signos, uma vez que o objeto dinâmico é aquele que determina o signo e que este tem a função de representar todo o contexto histórico e evolução no tempo da marca Louis Vuitton, sendo então, o objeto dinâmico dessa marca. As campanhas e peças publicitárias são signos constitutivos da complexidade do signo maior que é a marca Louis Vuitton.

A marca Louis Vuitton apresenta como principal diferencial a tradição, possuindo uma história que, desde o princípio, esteve relacionada à realeza. A maison explora um posicionamento de superioridade no que tange à qualidade e sofisticação dos produtos que oferta, trabalhando com uma comunicação integrada, de modo a evidenciar seus principais atributos. 


\section{CAMPANHA JOURNEY - CATHERINE DENEUVE, 2008}

Figura 1: Campanha Journey - Catherine Deneuve (2008)

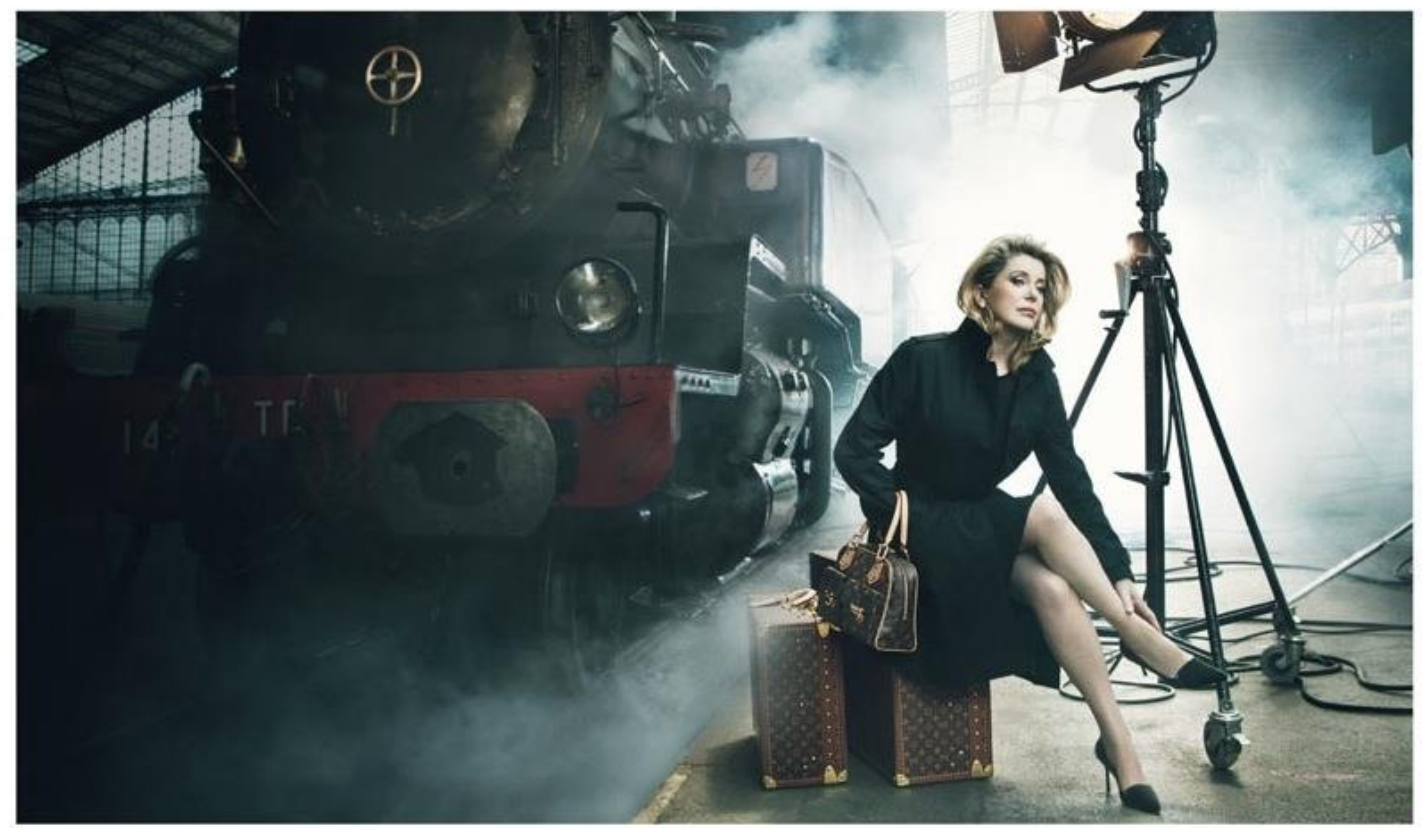

Fonte: <http://br.adforum.com/creativework/ad/player/12654913/sxi:8743395>

A campanha publicitária Journey, da marca Louis Vuitton, protagonizada pela atriz francesa Catherine Deneuve, foi veiculada no ano de 2008, produzida pela agência de publicidade Ogilvy\&Mather, de Paris, e fotografada por Annie Leibovitz, na estação de trem Austerlitz, em Paris.

\subsection{O ponto de vista qualitativo - icônico}

A análise da publicidade, sob o ponto de vista qualitativo-icônico, busca captar as impressões resultantes de uma primeira observação. Tais impressões são vagas e não passíveis de interpretação nesse momento, pois causam um efeito imediato que pode agradar, desagradar ou, até mesmo, não causar qualquer reação.

Em um primeiro momento de observação da imagem, é possível ver uma figura feminina de idade indefinida sentada sobre dois baús, segurando uma bolsa, sendo possivel reconhecer as inscrições $L V$ em tais objetos. Os baús e a bolsa estão fechados, não sendo possível identificar se a referida mulher está chegando ou partindo de viagem. A imagem sugere que ela está à espera de algo ou de alguém. Logo atrás da figura feminina, ao lado esquerdo da imagem, há um trem de modelo antigo, cujo movimento mostra-se, aparentemente, lento. 
Se pensarmos que o tempo é composto por elementos distintos e lineares do passado, presente e futuro, concluiríamos que podemos pensar nas coisas em termos de sua posição no tempo: à frente ou atrás no tempo. E é deste modo que nosso pensamento sobre os objetos, imagens e textos começam a se tornar estruturados e compostos pelo tempo. (HALL, 2008, p. 90)

No último plano da imagem, também ao lado esquerdo, é visível uma armação de ferro e vidros, semelhante a uma estação ferroviária. Ao lado direito, visualizase um refletor iluminado bem como vários cabos de energia espalhados pelo chão e, ao fundo, há a presença de uma névoa que contrasta com os tons escuros da imagem e ilumina o ambiente. A união de todos esses elementos remete a um tempo indefinido.

A mulher está sentada de pernas cruzadas, sua roupa escura possui uma textura lisa, em oposição à textura da bolsa e dos baús que se mostram cheios de detalhes. As pernas da mulher estão desnudas, mas tal cena não transmite vulgaridade, sua posição demonstra uma leve inclinação para frente, sendo que uma de suas mãos está em seu tornozelo e, a outra, dentro do bolso do sobretudo que a veste. A mulher é bastante elegante, trajando uma roupa clássica e sapatos de salto alto. Suas vestes são sóbrias e discretas, sugerindo bom gosto e atemporalidade.

A mulher não olha para nenhum objeto da imagem, seu olhar contemplativo para um ponto incerto sugere calma e distanciamento, bem como introspecção.

A composição visual tem predominância de linhas retas, no sentido horizontal e vertical, resultando em uma harmonia de linhas e formas reta. A composição forma um retângulo, distribuindo os elementos mais importantes em cada um dos vértices. No vértice superior esquerdo, há a locomotiva, no superior direito o foco de luz, no inferior direito a atriz e no esquerdo a legenda, parte verbal, que gera um efeito de sentido para a propaganda.

As cores trabalhadas na imagem direcionam o olhar do receptor, sendo que o vermelho, presente na parte inferior esquerda da composição, está direcionado para a exposição dos produtos, baús e bolsa Louis Vuitton, obtendo, dessa forma, um ponto focal destacado. O elemento visual luz pode ser entendido como o "[...] contraste formal entre o claro e o escuro" (OSTROWER, 2013, p. 157). Enquanto o claro gera a sensação de expansão, o escuro, de recuo. No anúncio, a luz favorece a leitura visual direcionando a atenção da direita para a esquerda. Na leitura da linguagem visual, alguns dos elementos constitutivos devem ganhar destaque, enquanto outros devem aparecer em segundo plano, complementando a imagem. Sendo assim, as superfícies são lisas e opacas, justamente para evidenciar os elementos luz e linha, enquanto o elemento cor complementa a leitura visual, apontando para o produto em questão.

Assim, as cores apresentam um contraste de temperaturas. Há o predomínio de cores frias, em especial o cinza e o negro e, em alguns pontos, tons esverdeados e azulados, em oposição aos tons mais quentes, marrom e vermelho. Os objetos de viagem, baús e bolsa, apresentam ferragens douradas que se tornam pontos de luminosidade na imagem.

O grande foco de luz, que irradia por trás da figura feminina, concede-lhe intenso destaque no todo da imagem, criando uma certa aura. 
A predominância dos volumes cúbicos harmoniza a composição visual, destacando, novamente, os elementos luz e linha. Tal fato ocorre em função da escolha dos produtos, nesse caso, os baús em formas cúbicas. Além do que, a forma cúbica da locomotiva também entra em consonância com o formato dos baús.

No que tange ainda à composição visual, os elementos presentes na imagem, na parte inferior direita, recebem uma maior sensação de peso visual, fazendo com que o receptor direcione seu olhar de cima para baixo. Considerando o estudo sobre peso e espaço realizado por autores como Ostrower (2013) e Arnheim (2014), tais elementos encontram-se dispostos na parte inferior do anúncio, com destaque para o lado direito, que apresenta um maior peso visual, como visto acima, chamando a atenção do receptor e favorecendo a memorização dos produtos.

Na imagem em análise, há um equilíbrio dinâmico, ou seja, o ponto focal está deslocado do centro geométrico do espaço visual. A composição fotográfica, ou seja, a organização dos elementos na fotografia, tais como posição, texturas, cores, formas, equilíbrio, é guiada pelo princípio dos três terços, ${ }^{1}$ cujo objetivo é capturar uma imagem visualmente equilibrada e agradável de se ver. A regra dos terços possibilita o melhor enquadramento da imagem, através de um exercício visual, no qual o fotógrafo, mentalmente, divide a imagem em três terços verticais e três terços horizontais, totalizando nove enquadramentos, conforme apresentado na figura abaixo. Desta forma, os elementos a serem mais destacados, ficarão posicionados nas intersecções entre as linhas, os denominados pontos de ouro. "Sendo assim, ao invés de centralizar o assunto, ele será posicionado nestes pontos, o que dará à foto uma composição mais elaborada. 0 objetivo é conseguir uma maior harmonia entre os elementos da foto."2

\footnotetext{
${ }^{1}$ Disponível em: <http://omeuolhar.com/artigos/que-regra-tercos>. Acesso em: 29 dez 2014.

2 Disponível em: <http://www.infoescola.com/fotografia/regra-dos-tercos/>. Acesso em: $29 \mathrm{dez} 2014$.
} 
Figura 2: Análise da imagem de acordo com a regra dos três terços
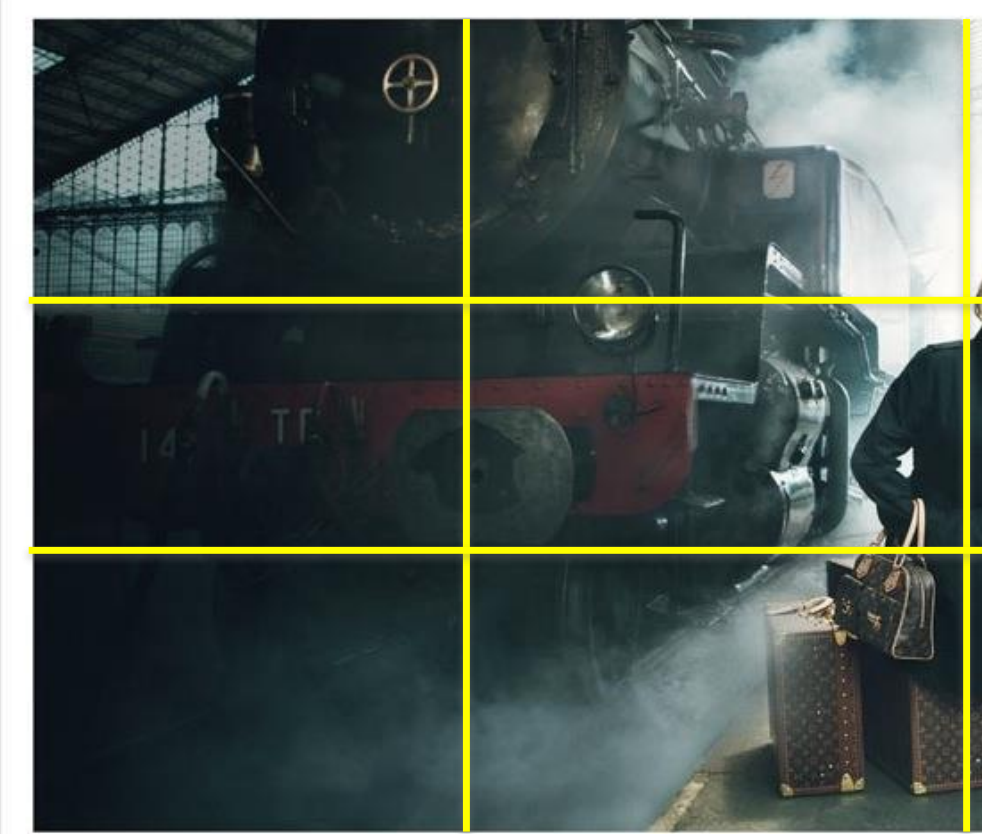

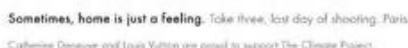
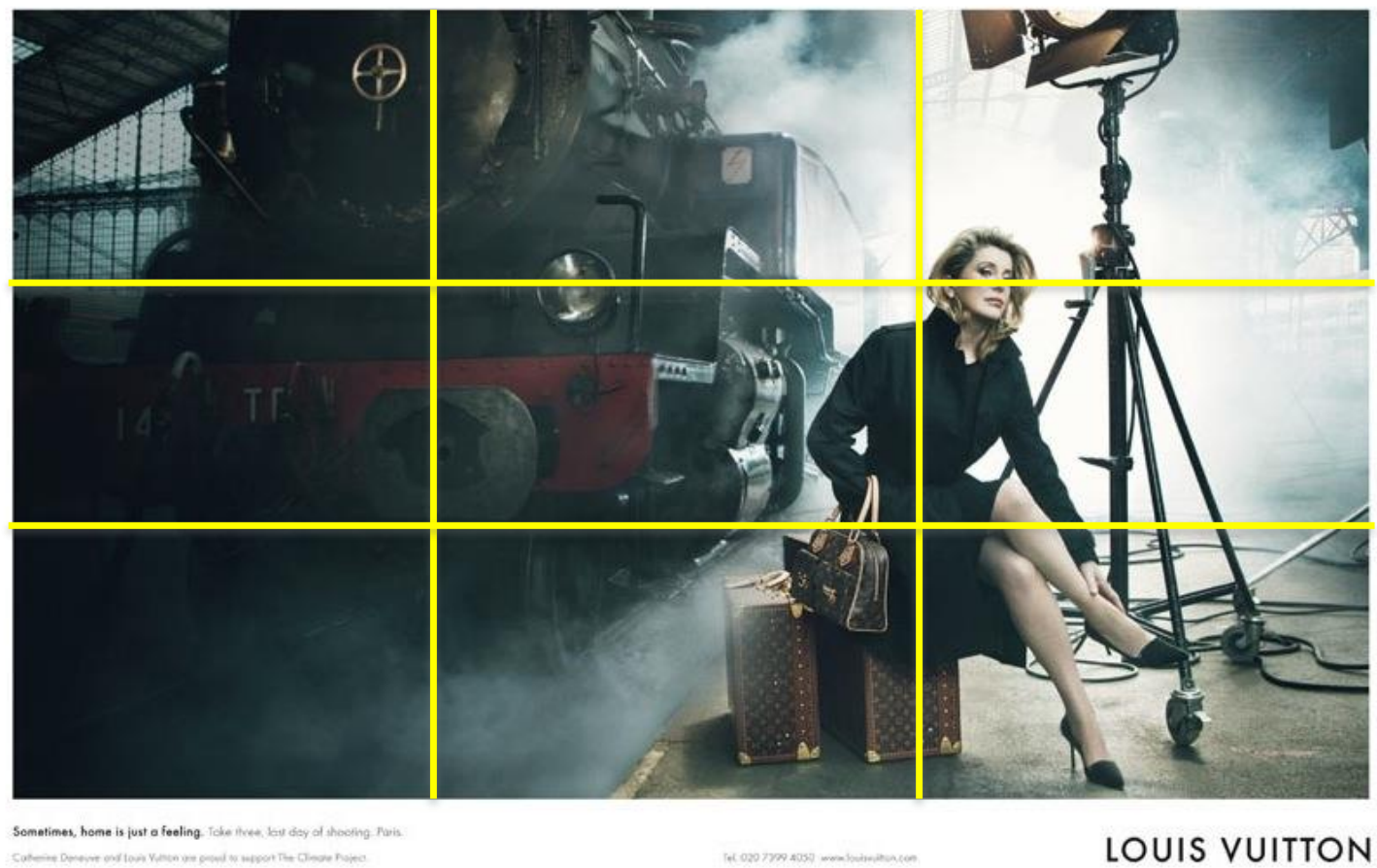

LOUIS VUITTON

Fonte: concepção da autora

A composição da imagem sugere intimismo, distanciamento, elegância, sobriedade, atemporalidade, sofisticação. Nesse nível de análise, os signos presentes são denominados quali-signos, sendo que quali se refere às qualidades. A sugestão, provocada por uma qualidade, possibilita o funcionamento do signo. "O quali-signo é uma qualidade que é um signo. Não pode, em verdade, atuar como signo, enquanto não se corporificar." (CP, 2.244 apude NÖTH, 2003 p. 76). Mas as qualidades estão aí, evidentemente, corporificadas na imagem, um sin-signo.

As qualidades desse signo, na sua relação com o objeto, são icônicas. Essas qualidades em si mesmas funcionariam como ícones puros. Entretanto, como elas estão corporificadas em uma imagem específica e singular, a imagem é um sin-signo no qual inerem qualidades.

Sendo assim, a leitura dessa imagem, sob o ponto de vista qualitativo-icônico, evoca um ambiente envolto em uma atmosfera vaga, o que é intensificado pelo contraste muito nítido entre dois lados da imagem, o esquerdo mais sombrio e o direito, banhado em luz. Esse contraste é acentuado porque, embora o trem se aproxime, a posição e o olhar da mulher solitária, mas bem acompanhada pelos utensílios que a rodeiam, the dirige as costas, com um ar de indiferença. A situação como um todo é bastante enigmática. Passemos, portanto, para o que o ponto de vista indicial tem a nos dizer. 


\subsection{0 ponto de vista singular - indicativo}

Após as primeiras impressões concernentes aos aspectos qualitativos, partese para uma observação mais detalhada, com o escopo de identificar os elementos que constituem aquilo que se apresenta aos sentidos. Na análise da imagem, sob o ponto de vista singular-indicativo, as qualidades são percebidas em função de sua existência concreta.

Antes de tudo, a figura da mulher, pela beleza e pela fama de que goza há anos, e pelas infindas imagens que foram dela extraídas e espalhadas por revistas, jornais e, certamente, pelos filmes que fez, é imediatamente identificada como a atriz Catherine Deneuve. Seus pertences, marcados com a assinatura LV, não menos famosa, remete à marca Louis Vuitton. Não é por acaso que a luz enquadra esses pontos focais da imagem, destacando-os e deixando o fundo levemente desfocado.

Sendo assim, é possível perceber a intenção de dispor os elementos de modo a orientar o direcionamento do olhar para determinados pontos fundamentais na leitura da imagem, ou seja, o olhar inicia a leitura da imagem identificando a locomotiva, o refletor de luz e segue percebendo os elementos dispostos na parte inferior do anúncio, a legenda e o principal ponto focal, a atriz Catherine Deneuve, sentada sobre os baús Vuitton.

A composição visual da imagem, bem como a distribuição dos elementos, proporciona a memorização do produto em razão de sua posição no espaço visual.

Sin-signos são signos de existência concreta. Todo existente só pode existir em um dado contexto. Por isso, sin-signos funcionam como índices de seus objetos de referência, ou seja, remetem ao seu contexto, indicam o universo ao qual pertencem. No caso dessa imagem, há alguns índices intensamente marcados: a imagem da mulher que, indubitavelmente, indica a atriz, Deneuve. A cor de seus pertences e a inscrição LV dispensam a legenda, pois são índices inconfundíveis da Louis Vuitton. $O$ trem e a estação, que aí é enquadrada metonimicamente, indicam viagem. A imagem contém qualidades internas que indicam se tratar de uma fotografia. Toda fotografia funciona como um feixe de índices. 0 tipo de foto e a distribuição de seus elementos indica que se trata de um anúncio publicitário, o que é confirmado pela relação indicial da foto com a legenda, que desempenha um papel declarativo. Trata-se, aqui, da Louis Vuitton, para ninguém duvidar.

Embora a inscrição LV sobre o inconfundível couro marrom sejam ambos imediatamente reconhecidos em função dos quali-signos próprios do lettering da inscrição, das cores e do tipo de couro, o aspecto indicial de uma marca lhe é fundamental. O que essa marca acumulou, ao longo do tempo, para se constituir como uma marca imediatamente reconhecível? Isso compõe o seu contexto de referência. Os contextos ou universos referenciais tanto da atriz quanto da marca são densos e extensos. Eles se referem aos objetos dinâmicos da imagem da atriz, que está longe de ser uma figura anônima, e da marca. Sob esse aspecto, a imagem é bastante astuciosa, nos índices internos que exibe para produzir um efeito final de destaque imperioso aos três índices que são soberanos na imagem: a atriz, a marca e a viagem. A imagem do trem, evidentemente, um trem antigo, contrasta com a modernidade da figura feminina e dos produtos Louis Vuitton que ela exibe. Esse contraste, longe de acentuar essa modernidade, funciona como índice da atemporalidade tanto da fama e da beleza da atriz quanto da marca. Em que momento, em que hora, em que situação, de ida ou de volta, se deu esse flagrante? 
Indefinido. Uma indefinição que funciona, no contexto da foto, para arrancar as figuras que importam do tempo e do espaço, estes que deveriam funcionar como elementos indexicais chave e que aí estão dessemantizados para acentuar os aspectos simbólicos da marca, sua aura e seu valor, como será visto a seguir.

\subsection{0 ponto de vista convencional - simbólico}

A campanha Journey, Louis Vuitton, pode ser considerada uma estratégia de persuasão comercial que objetiva transmitir os valores simbólicos da marca através de uma imagem a ser decodificada pelo receptor. "Todo processo publicitário implica uma sequência de dois atos, grosseiramente um de persuasão e um de venda." (SANTAELLA e NÖTH, 2010, p. 15)

A persuasão pode ser identificada como um "ato semiótico" que envolve a troca de mensagens entre o emissor, no caso em questão, a Louis Vuitton e o receptor da mensagem, o consumidor. "Seu alvo semiótico é a informação, a persuasão ou a criação de uma convicção." (ibid., p. 15)

A campanha Journey utiliza aspectos verbais e imagéticos para se comunicar com o receptor da mensagem. A forma verbal de comunicação se constitui com base na linguagem articulada, sendo lógica e racional, enquanto a não verbal utiliza imagens sensoriais variadas, tais como as visuais e auditivas, correspondendo à linguagem das metáforas e dos símbolos (AGUIAR, 2004).

O recurso não-verbal é ultra explorado nas publicidades de luxo, não sendo uma exceção nos anúncios da campanha em análise, como foi analisado acima, pois permitem interpretações variadas, que criam empatia com os consumidores, em função de experiências colaterais individuais. O uso de recursos imagéticos, sobretudo na publicidade de luxo, encontra respaldo no fascínio que as formas estéticas exercem sobre o ser humano. "Fascinação significa apenas que essas formas estéticas arrebatam as sensações humanas. Em razão do domínio dos aspectos sensíveis, os próprios sentidos passam a dominar o indivíduo fascinado." (HAUG, 1997, p. 67)

A celebridade endossadora do anúncio é a atriz francesa Catherine Deneuve, considerada uma das mulheres mais elegantes da história, representando um símbolo de beleza e sofisticação francês. A escolha da celebridade endossadora leva em conta os significados que a mesma transmitirá para a marca ou para o produto. Os atributos que uma personalidade pode conceder à mercadoria são extensos, como, por exemplo status, estilo de vida, aspectos demográficos, dentre outros. No caso de Deneuve, as características mais marcantes referem-se a suas "preferências suntuosas" (MCCRACKEN, 2012, p. 114). Destaque-se, ainda, a nacionalidade francesa de Catherine, nação na qual o luxo se diferenciou, assumindo os significados de opulência e magnificência que preserva na contemporaneidade.

A relação de Catherine com a França ultrapassa os limites territoriais. A atriz apoia as causas feministas do país, como a liberação do aborto e suas características físicas serviram como modelo da representação moderna do emblema do país, Marianne, símbolo feminino da liberdade e da República francesa. A imagem de Marianne se renova ao longo do tempo, através da associação de mulheres francesas contemporâneas e relevantes para a história do país, o que reflete a importância de Deneuve para a nação. 
Catherine Deneuve é reconhecida por sua discrição e refinamento, sendo considerada a musa da alta-costura. Estrelou campanhas publicitárias para o perfume n. 5 de Chanel e foi musa de Yves Saint Laurent. "A celebridade [...] se conecta com os significados por um longo prazo; 'possuem' seus significados porque elas os criaram num palco público pela força de uma intensa e repetitiva performance." (ibid., p. 119)

A atriz destacou-se em sua área de atuação, recebeu uma série de prêmios, sendo reconhecida dentro da França, bem como em âmbito internacional, mantendo o status de diva do cinema francês até os dias atuais. Na década de 1960, protagonizou o filme Belle de Jour (1967), tornando-se um símbolo sexual.

As características de Catherine, tais como beleza, sofisticação, elegância justificam sua presença no anúncio da Louis Vuitton, uma vez que ambas, a atriz e a marca representam a França como símbolos de luxo, tradição e atemporalidade. Embora a celebridade seja uma senhora de meia idade, continua sendo considerada exuberante e um modelo de beleza que envelhece de forma saudável e natural. Nesse ponto, pode-se ressaltar que a tradição da marca e a reputação da atriz permanecem inabaladas, mesmo diante de um mundo efêmero e em constante transformação, delineado pela fugacidade da moda.

A forma como Catherine está sentada, levemente inclinada para frente, além dos pés que seguem a mesma posição, pode ser interpretada como a vontade de seguir adiante, de avançar. As pernas cruzadas e desnudas simbolizam desembaraço, com um toque de sensualidade que, em momento algum, poderia ser confundido com vulgaridade (WEIL e TOMPAKOW, 2013, p. 66).

A escolha dos baús para o anúncio encontra pertinência no fato de retratar a origem da marca, o início de uma trajetória de sucesso da Louis Vuitton. A presença do trem e dos baús encontra ancoragem no título da campanha, Journey, uma referência aos caminhos trilhados pela atriz e pela marca, sendo direcionada a um público-alvo mais velho, sofisticado, conservador e requintado.

0 trem e os artigos Vuitton estão dispostos de forma que o olhar do receptor seja direcionado ao nome da marca, que funciona como efeito espelho de tais elementos.

A presença da névoa cria uma luminosidade na imagem, realçada pela luz do refletor, criando um cenário diferenciado, mágico e misterioso, o que serve para dar ênfase à reputação da atriz de mito inacessível, além de simbolizar o encantamento presente nos produtos da marca, sendo possível perceber que a névoa percorre o caminho do trem, destacando o baú e ampliando sua presença no fundo da imagem, estabelecendo uma ligação entre o passado e o presente, uma estratégia que alicerça, ainda mais, a questão de atemporalidade da marca.

A imagem do trem e o destaque da cor vermelha representam dinamismo, resgatando a conotação de riqueza que tal tonalidade já possuiu, em função do alto custo de sua fabricação que demandava corantes caros. No império de Carlos Magno (742-814) “[...] o que era vermelho pertencia ao Imperador" (HELLER, 2013, p. 62).

Os baús são os objetos mais representativos da marca, remetem à sua origem, a um passado endossado pela nobreza e as ferragens douradas de sua composição surgem como pontos de luz na imagem. "[...] em termos simbólicos, o ouro não se compara a nenhuma outra cor. Quem pensa em ouro pensa, primeiramente, no metal nobre. Ouro é dinheiro, é sorte, é luxo - isso determina a simbologia do ouro." (ibid., p. 227) 
Os cabelos de Catherine se destacam na imagem em função de sua tonalidade loiro reluzente. "Também os cabelos loiros, no lirismo, se tornam dourados." (ibid., p. 87)

Em relação ao estilo de vestuário proposto para a campanha, percebe-se total harmonia entre o estilo clássico representado por Catherine e a escolha dos artigos Vuitton, simbolizando um estilo elegante e atemporal, acentuado pela cor preta.

Catherine Deneuve aparece com uma maquiagem que destaca seu rosto e a deixa ainda mais bela "[...] o rosto humano é um imenso campo de metamorfoses e a decoração corporal (maquilagem, tatuagem, penteados) uma arte visual que sempre traduz um estatuto, colocando em evidência a beleza, a carga erótica e o prestígio social." (MALYSSE, 2008, p. 109)

Embora os sinais para o reconhecimento da estação de trem que serve como cenário estejam quase apagados, pode-se reconhecer, por algumas metonímias que se trata da estação de trem Austerlitz, em Paris.

O nome da referida estação ferroviária é uma homenagem à vitória francesa, em face do exército austro-russo, na batalha de Austerlitz, em 1805, comandada por Napoleão Bonaparte. Na batalha em questão, o imperador utilizou estratégias diferenciadas e consagrou-se como comandante do exército francês. Ao vencer tal conflito, a França anexou ao seu território terras Austríacas na Itália e na Bavária. A batalha realizou-se próxima à cidade de Austerlitz, o que justifica seu nome. A vitória das tropas francesas, nesse conflito, foi facilitada por um denso nevoeiro, que encobriu a chegada do exército napoleônico, rendendo os soldados adversários. Napoleão obteve grande êxito na Batalha de Austerlitz, iniciando um período de quase uma década de dominação francesa no continente europeu, sendo motivo de grande orgulho para o povo da França.

A utilização da estação ferroviária, na propaganda, exalta a tradição francesa, bem como a glória da nação. O nevoeiro da batalha também é retratado no anúncio, evidenciando a superioridade da marca e da atriz.

A parte verbal do anúncio é composta pela inscrição do nome da marca, Louis Vuitton e pela legenda que, em tradução livre, pode ser entendida como: sentir-se em casa não é um lugar, é um sentimento (NT). ${ }^{3}$ Dessa forma, o efeito de sentido gerado é que, independente das viagens que realize para gravar seus filmes, a França é sempre o lar de Catherine. Enquanto a casa apresenta um sentido nômade, em função das constantes locomoções da atriz, os baús que carrega guardam seus pertences, seus objetos mais íntimos, bem como sua história. Ainda nesse sentido, o anúncio apresenta os baús da marca tradicional de luxo, Louis Vuitton, ou seja, uma referência francesa que faz parte da vida da atriz. $E$ o consumidor que os adquirir passa a tê-los. Outro valor implícito nessa legenda é o de que, não importa para onde se vá, Louis Vuitton nos dará sempre a sensação íntima, confortável, confiante, de estar em casa.

\footnotetext{
${ }^{3}$ Être chez soicen'est pas un endroit, c'est un sentiment.
} 


\section{CONSIDERAÇÕES FINAIS}

A aplicação da teoria semiótica ao anúncio publicitário da marca Louis Vuitton permite a constatação de que os artigos da referida marca são apresentados como símbolos de diferenciação, poder, elegância e sofisticação, com destaque especial às cores marrom e bege, representando as cores institucionais da marca, evidenciando sua superioridade.

A produção em larga escala e a semelhança das funções apresentadas pelos produtos resultou na necessidade de diferenciação entre os fornecedores, culminando em um processo de divulgação das marcas e dos atributos de cada bem. "A marca torna-se um projeto de significados, onde o produto é apenas uma das suas manifestações." (CHEVALIER; MAZZALOVO, 2011, p. 267, NT).

Os bens de consumo, muito mais do que simples produtos, são a expressão do self de cada indivíduo, pois seu uso reflete a forma com a qual cada um quer ser identificado na sociedade, possuindo, dessa maneira, uma função simbólica fortemente alicerçada na publicidade. A utilização de estereótipos de beleza, perfeição e aceitação são ultra explorados na comunicação publicitária, resultando na criação de grupos aspiracionais e tendências de comportamento.

A publicidade constrói cenários de acolhimento, remetendo o receptor da mensagem à ideia de que somente o produto/benefício que ela oferta é capaz de proporcionar felicidade, satisfação plena e bem estar. Sendo assim, não é mais possivel conceber a publicidade somente como uma ferramenta de marketing que tem como função divulgar ofertas ou produtos. A linguagem publicitária acaba por transcender essa função, de sorte a consolidar o perfil da sociedade de consumo contemporânea.

A comunicação de produtos de luxo explora o lado mágico dos artigos que oferta, realçando o prestígio do usuário, funcionando como um eu estendido. A publicidade de luxo tem como função primordial exaltar as características imateriais dos produtos que oferta, tais como o prestígio da marca, a tradição, a exclusividade, a perfeição, a elegância e o desejo apresentado pelo consumidor em relação ao bem. A expansão do mercado de luxo utiliza o marketing como uma das principais ferramentas de gestão e, em um contexto de luxo globalizado, as marcas aumentam seus investimentos em publicidade. A propaganda é uma ferramenta indispensável na criação de atributos simbólicos aos produtos e marcas de luxo, além de diferenciar artigos da mesma categoria, sendo que as celebridades ou modelos utilizadas nas campanhas contribuem para a solidificação do posicionamento da marca, bem como com a imagem que o consumidor reterá do artigo.

$\mathrm{O}$ anúncio com a atriz francesa Catherine Deneuve corresponde ao início da campanha Journey, no ano de 2008. A escolha da celebridade, bem como dos baús, artigos tradicionais e prestigiosos da marca, exploram a tradição francesa no segmento de luxo, incluindo elementos de honra ao povo da França, destacando a atemporalidade da marca e de seus produtos.

Os anúncios publicitários são construídos através de referências presentes na cultura, que serão interpretadas pelo receptor da mensagem, de acordo com suas experiências colaterais. Na publicidade em questão, a marca Louis Vuitton é apresentada como sinônimo de luxo, elegância e sofisticação, independente do momento ou do contexto em que esteja inserida, tão universal quanto são os mais relevantes valores humanos. 


\section{REFERÊNCIAS}

AGUIAR, Vera Teixeira de. 0 verbal e o não verbal. São Paulo: Unesp, 2004.

ARNHEIM, Rudolf. Arte e percepção visual: uma psicologia da visão criadora: nova versão. Trad. Ivonne Terezinha de Faria. São Paulo: Cengage Learning, 2014.

BURKE, Peter. A Fabricação do rei. A construção da imagem pública de Luís XIV. Trad. Maria Luiza X. de A. Borges. Rio de Janeiro: Jorge Zahar Editor, 1994.

CHEVALIER, Michel; MAZZALOVO, Gérald. Management et marketing du luxe. Paris: Dunod, 2011.

HALL, Sean. Isto significa isso. Isso significa aquilo: guia de semiótica para iniciantes. Trad. Andréa Mariz. São Paulo: Rosari, 2008.

HAUG, Wolfgang Fritz. Crítica da estética da mercadoria. Trad. Erlon José Paschoal e Jael Glauce da Fonseca. São Paulo: Unesp, 1997.

HELLER, Eva. A psicologia das cores: como as cores afetam a emoção e a razão. Trad. Maria Lúcia Lopes da Silva. São Paulo: Gustavo Gili, 2013.

MALYSSE, Stéphane. A moda incorporada: antropologia das aparências corporais e megahair. In: OLIVEIRA, Ana Claudia de; CASTILHO, Kathia. Corpo e moda: por uma compreensão do contemporâneo. São Paulo: Estação das Letras e Cores Editora, 2008.

MCCRACKEN, Grant. Cultura \& consumo II: mercados, significados e gerenciamento de marcas. Trad. Ana Carolina Balthazar. Rio de Janeiro: MAUAD, 2012.

NÖTH, Winfried. Panorama da semiótica: de Platão a Peirce. São Paulo: Annablume, 2003.

OSTROWER, Fayga. Universos da arte. Campinas: Editora da Unicamp, 2013.

PEREZ, Clotilde. Signos da marca: expressividade e sensorialidade. São Paulo: Pioneira Thomson Learning, 2004.

SANTAELLA, Lucia. Semiótica aplicada. São Paulo: Pioneira Thomson Learning, 2012.

SANTAELLA, Lucia. Matrizes da linguagem e pensamento: sonora, visual, verbal: aplicações na hipermídia. São Paulo: Iluminuras, 2005

SANTAELLA, Lucia; NÖTH, Winfried. Estratégias semióticas da publicidade. São Paulo: Cengage Learning, 2010.

SEMPRINI, Andrea. A marca pós-moderna: poder e fragilidade da marca na sociedade contemporânea. Trad. Elisabeth Leone. São Paulo: Estação das Letras, 2006. 
WEIL, Pierre; TOMPAKOW, Roland. O corpo fala: a linguagem silenciosa da comunicação não verbal. Petrópolis: Vozes, 2013. 